\title{
Human papillomavirus in amniotic fluid
} Mack T Ruffin IV*1, Joanne M Bailey², Diane Roulston³, Daisy R Lee ${ }^{4}$,
Ruth Ann Tucker ${ }^{4}$, David C Swan ${ }^{4}$ and Elizabeth R Unger

Address: ${ }^{1}$ Department of Family Medicine, University of Michigan, 1018 Fuller St., Ann Arbor, MI 48109-0708, USA, ${ }^{2}$ Department of Obstetrics and Gynecology, University of Michigan, Nurse Midwives, F4835 Mott 0264, Ann Arbor, MI 48109-0264, USA, ${ }^{3}$ Department of Pathology, University of Michigan, 1301 Catherine Road, Ann Arbor, MI 48109-0602, USA and ${ }^{4}$ Division of Viral and Rickettsial Diseases, Centers for Disease Control and Prevention, 1600 Clifton Rd. NE B6109, Atlanta, GA 30329, USA

Email: Mack T Ruffin* - mruffin@umich.edu; Joanne M Bailey - jabailey@umich.edu; Diane Roulston - droulstn@umich.edu; Daisy R Lee - del5@cdc.gov; Ruth Ann Tucker - rat1@cdc.gov; David C Swan - dswan@cdc.gov; Elizabeth R Unger - eru0@cdc.gov

* Corresponding author

Published: 04 September 2006

BMC Pregnancy and Childbirth 2006, 6:28 doi:10.1186/147/-2393-6-28

This article is available from: http://www.biomedcentral.com/I47/-2393/6/28

(C) 2006 Ruffin et al; licensee BioMed Central Ltd.

This is an Open Access article distributed under the terms of the Creative Commons Attribution License (http://creativecommons.org/licenses/by/2.0), which permits unrestricted use, distribution, and reproduction in any medium, provided the original work is properly cited.

Received: 22 February 2006

Accepted: 04 September 2006

\begin{abstract}
Background: There is evidence to suggest that human papillomavirus (HPV) can cross the placenta resulting in in-utero transmission. The goal of this study was to determine if HPV can be detected in amniotic fluid from women with intact amniotic membranes.

Methods: Residual amniotic fluid and cultured cell pellets from amniocentesis performed for prenatal diagnosis were used. PGMY09/II LI consensus primers and GP5+/GP6+ primers were used in a nested polymerase chain reaction assay for HPV.

Results: There were I 46 paired samples from I 42 women representing I 39 singleton pregnancies, 2 twin pregnancies, and I triplet pregnancy. The women were 78\% Caucasian, 5\% African American, 14\% Asian, and 2\% Hispanic. The average age was 35.2 years with a range of $23-55$ years. All samples were $\beta$-globin positive. HPV was not detected in any of the paired samples.

Conclusion: Given the age range, race, and ethnicity of the study population, one would anticipate some evidence of HPV if it could easily cross the placenta, but there was none.
\end{abstract}

\section{Background}

Infection with human papillomaviruses (HPV) is causal in the development of genital and oral cancers [1,2]. HPV infection is considered a sexually transmitted infection among adolescents and adults [3]. Detection rates of HPV infection by polymerase chain reaction (PCR) have ranged widely between $1 \%$ and $20 \%$ in newborns of pregnant women without apparent infection in their cervix [47] and between $5 \%$ and $72 \%$ in women with HPV-related cervical diseases diagnosed during pregnancy [8]. Many investigators believe that infants are exposed to HPV and infected during vaginal delivery $[9,10]$. In contrast, some investigators have suggested that vertical transmission is possible without evidence of vaginal or cervical secretion contact of the fetus [11-16]. However, the number of women studied to confirm placental transmission of HPV has been limited.

The goal of this study was to determine if HPV could be detected in amniotic fluid from women with intact membranes. 


\section{Methods}

Human subject approval from the University of Michigan was obtained to use residual amniocentesis samples that were to be discarded. To be eligible for the study, pregnant women had to be undergoing clinically indicated amniocentesis and have intact membranes. The only information on the women available to the investigators was age, race/ethnicity, and number of fetuses present at time of sampling. All clinical assays related to chromosomal assessment of the fetus had been completed, and the residual amniotic fluid and amniotic cell culture pellets were retrieved from the cytogenetics laboratory.

Amniotic fluid samples (8-12 ml) were spun at $4500 \mathrm{rpm}$ for 30 minutes. After decanting the supernatant fluid, the pellet was suspended in $150 \mu \mathrm{L}$ of TrisEDTA buffer. The cultured cell pellets were resuspended in $200 \mu \mathrm{L}$ PBS. A $150 \mu \mathrm{L}$ volume of each sample was extracted using the Roche MagNA Pure LC instrument and the DNA isolation kit I resulting in a final volume of $150 \mu \mathrm{L}$.

We used a direct PCR method followed by a nested PCR method to detect HPV. The Roche line blot assay, based on L1 consensus PCR with biotinylated PGMY09/11 primer sets and $\beta$-globin as an internal control for sample amplification $[17,18]$ was used as previously described, with $10 \mu \mathrm{L}$ extract in each $50 \mu \mathrm{L}$ reaction. All samples were HPV gel-band-negative and Roche Prototype Strip Assaynegative after 40 cycles (reagents provided as a gift from Roche Molecular Systems, Inc., Pleasanton, CA).

For the nested reaction, five microliters of each L1 amplicon was added to a PCR reaction mix containing GP5+/ GP6+ [19] primers ( $1 \mu \mathrm{M}$ each) and run for an additional 40 cycles under the following conditions: 40 cycles of $94^{\circ} \mathrm{C}$ for $45 \mathrm{~s}, 48^{\circ} \mathrm{C}$ for $4 \mathrm{~s}, 38^{\circ} \mathrm{C}$ for $30 \mathrm{~s}, 42^{\circ} \mathrm{C}$ for $5 \mathrm{~s}$, $66^{\circ} \mathrm{C}$ for $5 \mathrm{~s}$, and $71^{\circ} \mathrm{C}$ for $1.5 \mathrm{~min}$. This was followed by a final extension of $10 \mathrm{~min}$ at $72^{\circ} \mathrm{C}$. Fifteen $\mu \mathrm{L}$ from each sample was analyzed on a $2 \%$ agarose gel.

The HPV assays were repeated using separate extractions, increased volumes of extracts in the PCR assays and reamplification of L1 consensus PCR products with PGMY primers.

The data was analyzed using SPSS 11 with frequency distributions of study participants by age, race, and ethnicity by HPV status.

\section{Results}

The residual amniotic fluid and cell pellets were collected from 142 women. There were 146 paired samples representing 138 singleton pregnancies, 2 twin pregnancies, 1 triplet pregnancy, and 1 singleton pregnancy with an egg donor. The women's average age was 35.2 years with a range from 23-55 years. The race and ethnicity was 78\% Caucasian, 5\% African American, 14\% Asian, and 2\% Hispanic. No other data were available on the women. No HPV was detected in any of the amniotic fluid or pellet cell samples. All samples were $\beta$-globin positive. There was no evidence of technical barriers to detecting HPV in samples if it was present.

\section{Discussion}

In this study, no HPV was detected in amniotic fluid or culture cell pellets from 142 pregnant women with intact amniotic membranes. Other investigators have reported the upper 95\% confidence interval for detection of perinatal transmission from women with any evidence of genital HPV is only $2.8 \%$ [7]. Worda and colleagues found no HPV in amniotic fluid taken just prior to a cesarean delivery in 153 Austrian women with intact membranes [10]. With 142 amniotic samples, we have $80-85 \%$ power to detect prevalence of HPV from $1 \%$ to $10 \%$. Therefore, the lack of detecting HPV in the amniotic samples is not due to inadequate number of samples.

This study was not able to actually determine the HPV status of the study participants or their risk for having HPV. It is possible that none of the women had ever been infected or were not currently infected with HPV. Other studies addressing the issue of vertical transmission of HPV have reported that $12-36 \%$ of pregnant women asymptomatic for HPV were positive for HPV $[8,10,16,20]$. The population characteristics of these studies were similar to this study with a reported age range of 18-45 years and primarily Caucasian women except studies conducted in Asian countries $[8,10,16]$. The similarities between our study population and others suggest that $12-36 \%$ of the pregnant women should have been infected with HPV $[6,8,10,11,16,20,21]$. Yet, no HPV was detected in the amniotic fluid.

\section{Conclusion}

Perinatal transmission of HPV clearly does occur; juvenile onset recurrent respiratory papillomatosis is a documented rare outcome of infection with HPV. This occurs in 7 of every 1000 infants born to a mother with genital warts [22]. Some investigators have suggested that infants are exposed and infected by HPV during a vaginal delivery [9]. Studies have documented that there is poor concordance between parents' genital HPV and newborns' oral/ genital HPV [20]. In contrast, some investigators have suggested that vertical transmission is possible without evidence of vaginal or cervical secretion contact of the fetus [11-15]. However, this study and others suggest that vertical transmission without exposure to vaginal or cervical secretions is extremely unlikely $[8,10]$. 


\section{Competing interests}

The author(s) declare that they have no competing interests.

\section{Authors' contributions}

MR and JB participated in concept development, study design, implementation, and coordination; data analysis, and drafting the manuscript. DR collected the data and coordinated the sample numbers with demographic data. DRL, RAT, DCS, and ERU participated in the HPV assays and drafting the manuscript.

\section{Acknowledgements}

The authors thank Kathleen Crawford for assistance in retrieving anonymous materials from the cytogenetics laboratory and Miriam Lawson, Sonya Patel, and Juanita Onyekwuluje for assistance with laboratory testing.

Drs. Ruffin and Bailey were supported by $\mathrm{NCl}$ Grant CA080846. The funding agency had no role in the study design, data collection, analysis, interpretation of the data, writing of the manuscript or the decision to submit the manuscript for publication.

\section{References}

I. Schiffman MH, Bauer HM, Hoover RN, Glass AG, Cadell DM, Rush BB, Scott DR, Sherman ME, Kurman RJ, Wacholder S, Stanton CK Manos MM: Epidemiologic evidence showing that Human Papillomavirus infection causes most cervical intraepithelial neoplasia. I Nat/ Cancer Inst I 993, 85( I 2):958-964.

2. Gillison ML, Koch WM, Capone RB, Spafford M, Westra WH, Wu L, Zahurak ML, Daniel RW, Viglione M, Symer DE, Shah KV, Sidransky $\mathrm{D}$ : Evidence for a causal association between human papillomavirus and a subset of head and neck cancers [see comments]. J Natl Cancer Inst 2000, 92(9):709-720.

3. Munoz N: Human papillomavirus and cancer: the epidemiological evidence. J Clin Virol 2000, I 9(I-2): I-5.

4. Pakarian F, Kaye J, Cason J, Kell B, Jewers R, Derias NW, Raju KS, Best JM: Cancer associated human papillomaviruses: perinatal transmission and persistence. Br J Obstet Gynaecol 1994, I0I(6):5|4-5I7.

5. Syrjanen S, Puranen M: Human papillomavirus infections in children: the potential role of maternal transmission. Crit Rev Oral Biol Med 2000, I I(2):259-274.

6. Puranen M, Yliskoski M, Saarikoski S, Syrjanen K, Syrjanen S: Vertical transmission of human papillomavirus from infected mothers to their newborn babies and persistence of the virus in childhood. Am J Obstet Gynecol 1996, 174(2):694-699.

7. Watts DH, Koutsky LA, Holmes KK, Goldman D, Kuypers J, Kiviat NB, Galloway DA: Low risk of perinatal transmission of human papillomavirus: results from a prospective cohort study. Am J Obstet Gynecol 1998, I 78(2):365-373.

8. Smith EM, Johnson SR, Cripe T, Perlman S, McGuinness G, Jiang D, Cripe L, Turek LP: Perinatal transmission and maternal risks of human papillomavirus infection. Cancer Detect Prev 1995, 19(2): 196-205.

9. Tseng CJ, Liang CC, Soong YK, Pao CC: Perinatal transmission of human papillomavirus in infants: relationship between infection rate and mode of delivery. Obstet Gynecol 1998, 9I(I):92-96.

10. Worda C, Huber A, Hudelist G, Schatten C, Leipold H, Czerwenk $\mathrm{K}$, Eppel $\mathrm{W}$ : Prevalence of cervical and intrauterine human papillomavirus infection in the third trimester in asymptomatic women. J Soc Gynecol Investig 2005, I 2(6):440-444.

II. Puranen MH, Yliskoski MH, Saarikoski SV, Syrjanen KJ, Syrjanen SM: Exposure of an infant to cervical human papillomavirus infection of the mother is common. Am J Obstet Gynecol 1997, | 76(5): 1039-1045.

12. Xu S, Liu L, Lu S, Ren S. Clinical observation on vertical transmission of human papillomavirus. Chin Med Sci J 1998, I3(I):29-31.
13. Favre M, Majewski S, De Jesus N, Malejczyk M, Orth G, Jablonska S: A possible vertical transmission of human papillomavirus genotypes associated with epidermodysplasia verruciformis. J Invest Dermatol 1998, I I I(2):333-336.

14. Wang X, Zhu Q, Rao H: Maternal-fetal transmission of human papillomavirus. Chin Med J (Engl) 1998, I I I (8):726-727.

15. Tseng CJ, Lin CY, Wang RL, Chen LJ, Chang YL, Hsieh TT, Pao CC: Possible transplacental transmission of human papillomaviruses. Am J Obstet Gynecol 1992, I66(I Pt I):35-40.

16. Deng $D$, Wen $L$, Chen $W$, Ling $X$ : Asymptomatic genital infection of human papillomavirus in pregnant women and the vertical transmission route. J Huazhong Univ Sci Technolog Med Sci 2005, 25(3):343-345

17. Gravitt PE, Peyton CL, Apple RJ, Wheeler CM: Genotyping of $\mathbf{2 7}$ human papillomavirus types by using LI consensus PCR products by a single-hybridization, reverse line blot detection method. J Clin Microbiol 1998, 36( (10):3020-3027.

18. Gravitt PE, Peyton CL, Alessi TQ, Wheeler CM, Coutlee F, Hildesheim A, Schiffman MH, Scott DR, Apple RJ: Improved amplification of genital human papillomaviruses. J Clin Microbiol 2000, 38(I):357-36I.

19. Fuessel Haws AL, He Q, Rady PL, Zhang L, Grady J, Hughes TK, Stisser K, Konig R, Tyring SK: Nested PCR with the PGMY09/I I and GP5(+)/6(+) primer sets improves detection of HPV DNA in cervical samples. J Virol Methods 2004, I 22(I):87-93.

20. Smith EM, Ritchie JM, Yankowitz J, Swarnavel S, Wang D, Haugen TH, Turek LP: Human papillomavirus prevalence and types in newborns and parents: concordance and modes of transmission. Sex Transm Dis 2004, 3 I ( I):57-62.

21. Puranen M, Syrjanen K, Syrjanen S: Transmission of genital human papillomavirus infections is unlikely through the floor and seats of humid dwellings in countries of high-level hygiene. Scand J Infect Dis 1996, 28(3):243-246.

22. Silverberg MJ, Thorsen P, Lindeberg H, Grant LA, Shah KV: Condyloma in pregnancy is strongly predictive of juvenile-onset recurrent respiratory papillomatosis. Obstet Gynecol 2003, I0I(4):645-652.

\section{Pre-publication history}

The pre-publication history for this paper can be accessed here:

http://www.biomedcentral.com/1471-2393/6/28/prepub

Publish with BioMed Central and every scientist can read your work free of charge

"BioMed Central will be the most significant development for disseminating the results of biomedical research in our lifetime. "

Sir Paul Nurse, Cancer Research UK

Your research papers will be:

- available free of charge to the entire biomedical community

- peer reviewed and published immediately upon acceptance

- cited in PubMed and archived on PubMed Central

- yours - you keep the copyright

BiolMedcentral 